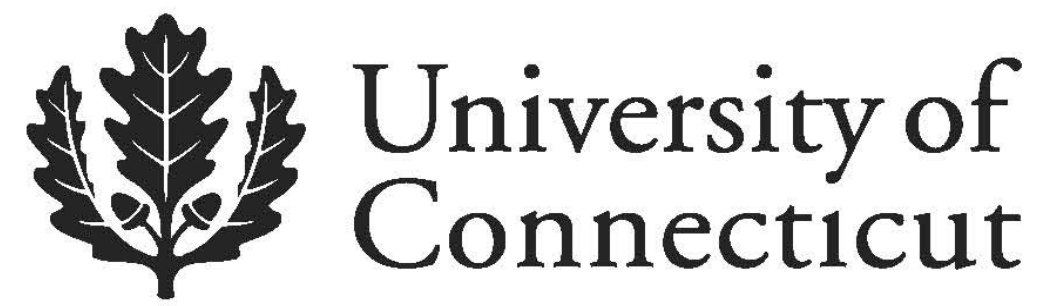

Department of Economics Working Paper Series

The Bank Lending Channel and Monetary Policy Rules for European Banks: Further Extensions

Nicholas Apergis

University of Piraeus

Stephen M. Miller

University of Nevada, Las Vegas

University of Connecticut

Effrosyni Alevizopoulou

University of Piraeus

Working Paper 2012-10

July 2012

341 Mansfield Road, Unit 1063

Storrs, CT 06269-1063

Phone: (860) 486-3022

Fax: (860) 486-4463

http://www.econ.uconn.edu/

This working paper is indexed on RePEc, http://repec.org/ 


\title{
The Bank Lending Channel and Monetary Policy Rules for European Banks: Further Extensions
}

\author{
Nicholas Apergis \\ Department of Banking \& Financial Management \\ University of Piraeus \\ 18534 Piraeus \\ GREECE \\ Stephen M. Miller* \\ Department of Economics \\ University of Nevada, Las Vegas \\ 4505 S. Maryland Parkway \\ Box 456005 \\ Las Vegas, Nevada, 89154-6005 \\ UNITED STATES \\ stephen.miller@unlv.edu \\ and

\section{Effrosyni Alevizopoulou} \\ Department of Banking \& Financial Management \\ University of Piraeus \\ 18534 Piraeus \\ GREECE
}

\begin{abstract}
The monetary authorities affect the macroeconomic activity through various channels of influence. This paper examines the bank lending channel, which considers how central bank actions affect deposits, loan supply, and real spending. The monetary authorities influence deposits and loan supplies through its main indicator of policy, the real short-term interest rate. This paper employs the endogenously determined target interest rate emanating from the central bank's monetary policy rule to examine the operation of the bank lending channel. Furthermore, it examines whether different bank-specific characteristics affect how European banks react to monetary shocks. That is, do sounder banks react more to the monetary policy rule than less-sound banks. In addition, inflation and output expectations alter the central bank's decision for its target interest rate, which, in turn, affect the banking system's deposits and loan supply. Robustness tests, using additional control variables, (i.e., the growth rate of consumption, the ratio loans to total deposits, and the growth rate of total deposits) support the previous results.
\end{abstract}

Keywords: $\quad$ Monetary policy rules, bank lending channel, European banks, GMM methodology

JEL classification: G21, E52, C33.

* corresponding author 


\section{The Bank Lending Channel and Monetary Policy Rules for European Banks: Further Extensions}

\section{Introduction}

The monetary transmission mechanism includes various channels through which the monetary authorities can affect the macroeconomy. Two main channels include the interest rate (money view) and credit (credit view) channels. In the money view, monetary policy affects aggregate demand through real interest rates, whereas in the credit view, monetary policy facilitates the transmission of policy through the availability of deposits and loans (Hernando and Pages, 2001). A sub-channel within the credit view (bank lending channel) relates to the supply of credit and "stems from financial market incompleteness and relies on imperfect substitutability” (Gambacorta, 2005, p. 1737). An alternative sub-channel within the credit view (balance sheet channel) relates to the balance sheet and income statements and the informational frictions that alter the external finance premium.

Changes in bank reserves cause changes in bank deposits and loans, resulting initially from central bank's adjustment in its target interest rate. This paper extends Apergis and Alevizopoulou (2012) and examines the effects on the operation of the bank lending channel when we employ different measures of the central banks' primary monetary policy instrument (i.e., a target interest rate), which depends on a set of macroeconomic variables. In other words, this paper investigates the effect on the bank lending channel in a number of euro area economies, since most European developed economies rely much more heavily on indirect bank finance rather than direct stock and bond market finance, where we use different interest rate rules as alternative monetary policy indicators. A limited literature exists on direct econometric estimates of the European Central Bank (ECB) monetary policy rules. Although Hayo and Hoffman (2005) estimate such rules, their empirical analysis does not examine flexible forms of monetary policy rules.

Apergis and Alevizopoulou (2012) consider the bank lending channel for a group of 
six European countries - Austria, Belgium, Finland, France, Germany, and the Netherlands as well as Denmark and the UK as separate analyses. They specify interest rate policy rules that depend on timing issues - lagged, current, or forecast values to inform the policy rule. They then compare the results across the different policy rules. Their empirical findings show that the bank lending channel operates most robustly to forward-looking monetary policy rules.

Our analysis differs and extends that of Apergis and Alevizopoulou (2012) in several important ways. First, we include bank specific information to see if differences in bank performance affect how the bank responds to changes in monetary policy through the bank lending channel. For example, do sound banks respond more vigorously to a monetary policy change than do less-sound banks? Second, we consider the robustness of our findings by including other variables to control for loan demand - the growth rate of consumption, the ratio of deposits to loans, and the growth rate of deposits. Third, for both the interest rate rules and the bank lending channel estimations, our GMM estimation uses up to four lags whereas Apergis and Alevizopoulou (2012) only consider up to two lags. Fourth, the bank lending channel estimates in our paper use deviations from the mean, whereas Apergis and Alevizopoulou (2012) do not. Fifth, one of the three interest rate rules, the forward-looking rule, requires forecasts of the inflation rate and the output gap. Apergis and Alevizopoulou (2012) provide forecasts of inflation, but not the output gap. We provide forecasts of both. In addition, our forecast of the inflation rate includes additional information. Finally, we collect the data from scratch, given updated data bases from which to draw our sample. As a result, the coverage of banks differs slightly and the data on the banks reflects new revisions.

We organize the rest of the paper as follows. Section 2 reviews the literature concerning the bank lending channel and interest rate rules. Section 3 presents and analyses the data. Section 4 outlines the methodologies used, first, to estimate the different monetary 
policy rules and, second, to estimate the effect of monetary policy on the bank lending channel. Finally, Section 5 reports the findings and Section 6 concludes.

\section{Literature Review}

\subsection{The Bank Lending Channel}

This study considers how the monetary authorities affect the macroeconomy through the bank lending channel, which largely depends on the quantities of deposits and loans and the factors that determine these quantities. In particular, the monetary authorities implement an expansionary (contractionary) policy by increasing (decreasing) bank reserves and lowering (raising) interest rates. As reserves expand (contract), the banking system increases (decreases) deposits and loans. Therefore, businesses and consumers, who depend on bank lending, can increase (decrease) their purchases of durable goods and capital for investment. Hence, expansions (contractions) in bank reserves affect output positively (negatively) (Golodniuk, 2006).

Three necessary conditions must exist for the bank lending channel to exert significant economic effects. First, firms must respond differently to different types of finance. That is, they must depend on bank loans, since they cannot rely on other types of finance (Oliner and Rudenbusch, 1995). Second, the supply of loans must respond to changes in reserves that the central bank imposes on the system. For instance, when confronted with a restrictive monetary policy, banks cannot easily offset the decrease in funds from deposits by raising funds from other sources. In other words, banks face restrictions in issuing uninsured liabilities to replace the shortfall in deposits (Oliner and Rudenbusch, 1995; Disyatat, 2010). Third, some imperfections must exist in the adjustment of the aggregate price level. That is, monetary policy will exert no effect, if prices can adjust proportionally and quickly with changes in the money supply (Golodniuk, 2006).

The existing literature on the bank lending channel searches for this channel in 
different economies or in a group of countries. More specifically, it examines whether the effect on lending responds differently, depending the influence of the banking system, which, in turn, depends on such characteristics as capitalization, asset size, and liquidity. Most studies on euro area economies provide empirical support for the presence of the channel, while the empirical analysis for the US case provides mixed results (Ehrmann et al., 2003; Gambacorta, 2005). Juurikkala et al. (2011) also find evidence that supports the presence of the channel in Russia. The empirical evidence also supports the idea that well capitalized and liquid banks experience more insulation from monetary policy changes than banks that exhibit low capital and liquidity ratios. In addition, the majority of studies show that small banks do not exhibit more sensitivity to monetary policy shocks than large banks (Peek and Rosengren, 1995; Gambacorta, 2005; Golodniuk, 2006). Other empirical studies, however, find that large banks, in combination with high capitalization ratios, respond less to monetary policy shocks (Kishan and Opiela, 2000).

Empirical implementation faces an important problem. More precisely, merely observing that both output and bank loans decrease after a negative change in monetary policy does not necessarily imply that this change reflects a reduction in loan supply (Oliner and Rudenbusch, 1995; Brissimis et al., 2001). Such changes, however, may only reflect a reduction in loan demand. For instance, a tight monetary policy increases interest rates and, consequently, generates higher costs, which do not favor investment, leading to a fall in loan demand and, therefore, in the volume of loans. To resolve this issue, the literature either analyzes microeconomic data on firms and banks (Kashyap et al., 1993), rather than macroeconomic data, or it uses a number of macroeconomic control variables (i.e., GDP and inflation) that affect the demand for loans.

\subsection{Monetary Policy Rules}

Macroeconomists model the policy process as follows. The central bank chooses its operating 
targets to optimize its objective function subject to the macroeconomic model of the economy. Hence, they derive central bank reaction functions or monetary policy rules that describe how central banks alter their policy in response to macroeconomic changes. The central bank most frequently uses the short-term interest rate as the policy instrument and, therefore, "monetary policy rules" typically mean "interest rate rules” (Fourcans and Vranceanu, 2004).

Gerdesmeier and Roffia (2003) identify three main reasons for the interest in central bank reaction functions. First, an interest rate rule makes the evaluation of the central bank feasible. Second, a rule provides a good forecasting tool to evaluate the changes that the central bank imposes on the policy instrument. Finally, the correct reaction function plays an important role in estimating the entire macro model, when the model includes rational expectations.

Interest rate rules model the interest rate as depending on deviations of a set of macroeconomic variables, such as the inflation rate and output, from their target values. Taylor (1993) shows that monetary policy in the U.S. conforms to a contemporaneous interest rate rule, where the short-term interest rate depends on deviations of the inflation rate and real output from the target inflation rate and potential output, respectively. Moreover, such a rule closely follows observed movements in that interest rate. More precisely, the target federal funds rate equals the long-run equilibrium real interest rate plus the current inflation rate, plus coefficients multiplied by the deviations of inflation and real output from the target inflation rate and potential output, respectively. When the inflation rate exceeds (falls below) its target, the rule recommends an increase (decrease) in the interest rate. This term captures the goal of the central bank to achieve price stability.

With a positive (negative) output gap, the Taylor rule recommends an increase (decrease) in the interest rate. Kozichi (1999) argues that the output gap plays a forward- 
looking role, since a positive gap signals potential increases of the inflation rate in the future. Therefore, adjustments of the interest rate, vis-à-vis the output gap, implement policy responses aimed at preempting an expected increase in the future inflation rate. The specification of the original Taylor rule is as follows:

$$
i_{t}=\pi_{t}+\bar{r}+0.5\left(\pi_{t}-\pi^{*}\right)+0.5 x_{t}
$$

where $i_{t}$ is the target nominal interest rate, $\pi_{t}$ is the inflation rate, $\bar{r}$ is the long-run equilibrium real interest rate, assumed to equal 2 percent, $\pi^{*}$ is the target inflation rate, also assumed to equal 2 percent, and $x_{t}$ is the output gap.

This contemporaneous Taylor rule facilitates a good interpretation of the historical monetary policy actions of the Federal Reserve, as mentioned in Orphanides (2003), suggesting that this rule serves as a "useful organizing device for interpreting past policy decisions and mistakes. However, the adoption of the Taylor-type framework for policy analysis is not insurance that past policy mistakes would not have occurred.” (p. 984).

Nevertheless, the Taylor rule possesses certain limitations. First, central banks do not know the contemporaneous output and inflation gap when setting the interest rate for a given time. To address this problem, one can use lagged output and inflation rate gap data (i.e., backward-looking rules). Or, one can replace current measures of these variables with forecasts (i.e., forward-looking rules).

Second, the contemporaneous Taylor rule imposes precise weights (i.e., 0.5) that represent the policy responsiveness to deviations of inflation and output from their targets. In addition, several measures of the inflation rate and the output gap exist and, therefore, researchers can use different measures.

Third, the contemporaneous Taylor rule does not incorporate interest rate smoothing. Observation suggests that central banks smooth interest rate movements, which researchers can incorporate into the contemporaneous Taylor rule (Kozichi, 1999; Woodford, 1999). 
Gerdesmeier and Roffia (2003) argue that interest rate smoothing may reflect optimal “monetary policy inertia”. Levin et al. (1999) and Woodford (1999) argue that policy inertia by affecting expectations of future policy and economic developments influences the ultimate goals, such as real GDP or inflation. Orphanides (2001) suggests that interest rate smoothing may reflect data uncertainty. Furthermore, central banks also want to stabilize financial markets, since abrupt changes in interest rates may disrupt bond and equity markets. This interest in financial market stability as well as the learning process through which central banks behave leads them to place some weight on the previous level of the interest rate (Woodford, 1999). Woodford (1999) also argues that with forward-looking inflation expectations, optimal policy may adjust the interest rate with some inertia because this smoothing provides leverage with respect to longer-term interest rates, which transmits monetary policy decisions to aggregate demand and the real economy. Finally, Rudebusch (2002) argues that the interest rate smoothing term may compensate for the misspecification of empirical rules that display substantial partial adjustments and that do not take into consideration serially correlated shocks.

The contemporaneous Taylor rule conforms to two interpretations: a narrow interpretation (i.e., it's the specific algebraic form mentioned above) or a broader interpretation. Orphanides (2003) argues that the broad interpretation introduces a degree of flexibility that overcomes the limitations of the contemporaneous framework. Taylor also emphasizes that one can interpret the rule as a monetary policy program, which the central bank uses to attain the fundamental policy objectives. In other words, one should not use the rule as a "mechanical formula," but rather as a guiding principle for the monetary authorities.

The existing literature debates whether the backward-looking or forward-looking rules better fit historical data when compared to the contemporaneous rule. Taylor (1999) argues that forward-looking rules may incorporate additional variables beyond the inflation 
and output terms that may improve the forecast. But, Haldane and Batini (1999) find that the interest rate setting by the European Central Bank (ECB) dominates such forward-looking rules. Taylor (1999) reports that in fact forecasts use current and lagged data and hence, forward-looking rules depend on current and lagged data as well.

Greenspan (1999) argues that using past macroeconomic behavior to form rules embodies a "notion" that the future will mimic the past. Meyer (2002) also argues that while forecasts play an important role in the implementation of monetary policy, future values (forecasts) do not play a role in the standard Taylor rule. Hence, we can view monetary policy as a forward-looking process, which ought to take into consideration all available information to form adequate policy rules (Orphanides, 2003). Many argue that central banks behave in a forward-looking manner and, therefore, the policy rule must incorporate such forward-looking behavior. Moreover, since monetary policy transmission operates with at least one lag, it directs the monetary authorities to anticipate inflation and not rely on its current value (Gerdesmeier and Roffia, 2003).

Clarida et al. (1998, 2000) adopt this approach and replace current and recent outcomes of output and inflation with forecasts of these variables. Fourcans and Vranceanu (2004) also apply this procedure for the ECB's interest rate rule. Their results indicate that the response of the interest rate to deviations of future inflation from its target exerts a stronger effect than if the rule incorporates current inflation. Finally, Fendel and Frenkel (2006) estimate different versions of the forward-looking rule for the case of the ECB, documenting that the ECB applies a Taylor-type rule to its monetary policy.

In sum, debate continues about the efficacy of contemporaneous, backward-looking, and forward-looking interest rate rules As a result, we shall use all approaches in our econometric analysis that follows. 


\section{Data Description}

\subsection{Interest Rate Rule Data Description}

We collect quarterly data from Datastream and Bloomberg databases to estimate interest rate rules for three different economies: a European group (i.e., Austria, Belgium, Finland, France, Germany, and the Netherlands, countries using the euro as a common currency), Denmark, and the United Kingdom. Denmark and the U.K., although operating with their own currency, however, follow the monetary policy of the euro zone, but still maintain some degree of autonomy. We did not consider the remaining Eurozone economies due to unavailability of continuous banking data over the time span of the paper. For each country, the rate of change in the consumer price index measures inflation, while we detrend real GDP, using the Hodrick-Prescott filter, to measure potential output and the output gap. We use the following short-term interest rates: the EONIA interest rate for the ECB on main refinancing operation (MRO), which is a short-term open market operation in form of reverse transactions that allows it to control the degree of liquidity in the interbank market; the Danish discount rate of the Danmarks Nationalbank; and the bank rate of the Bank of England. The analysis spans 2000 through 2009, using quarterly data. We construct weighted averages of the Euro-group variables, an approach similar to that recommended by the International Monetary Fund.

\subsection{Bank Lending Channel Data Description}

We collect annual data of total loans as the dependent variable that come from the BankScope database, spanning 2000 through 2009. ${ }^{1}$ In particular, we use a sample of 739 European commercial and savings banks. The European group of countries includes Austria, Belgium, Finland, France, Germany, and the Netherlands, which we use as a group, as well as Denmark and the United Kingdom separately. Table 1 reports the countries and the

\footnotetext{
${ }^{1}$ The BankScope database does not report quarterly data for our purposes.
} 
number of banks.

As noted above, we collect short-term interest rates, which proxy for monetary policy, from the Bloomberg database. Real GDP values and inflation rates for each country come from Datastream to control for demand effects (i.e., to isolate changes in total loans, which are caused by movements in loan demand). We also use bank-specific characteristics in the analysis for the bank lending channel and, therefore, we collect data concerning the financial strength of a bank from BankScope. More specifically, we use the bank capitalization measured by equity to total assets, bank size measured by total assets, and bank liquidity measured by the ratio of liquid assets to total assets. Finally, we use two more variables to implement robustness checks -- consumption of each country from Datastream and total deposits from the BankScope database.

We use quarterly data for the estimation of our three different interest rate rules (see Section 4). Since the BankScope data on bank-specific variables only come at the annual frequency, we use the interest rate rules estimated with quarterly data to generate annual forecasts (by choosing the last observation of the fourth quarter) and to combine them with the analysis of the bank-lending channel (in which all variables are set on an annual basis).

\section{The Econometric Specifications}

\subsection{The Interest Rate Rule}

We largely adopt the methodology from Clarida et al. (1998) and, therefore, borrow their notation. We measure monetary policy by the short-term interest rate. This allows the central bank to choose the level of the interest rate from period to period and conduct policy. More specifically, central banks vary the nominal interest rate -- the target rate -- to control effectively the real interest rate. We estimate this target rate as follows:

$$
i_{t}^{*}=\bar{i}+\beta\left[E\left(\pi_{t+1} / \Omega_{t}\right)-\pi^{*}\right]+\gamma E\left(x_{t} / \Omega_{t}\right),
$$

where $i^{*}$ is the target interest rate, $\pi^{*}$ is the target inflation rate, $\bar{i}$ is the long-run 
equilibrium nominal interest rate, $\pi_{t+1}$ is the inflation rate between periods $t$ and $t+1$, and $x_{t}$ is the output gap, the difference between output and its potential level. Furthermore, $\mathrm{E}$ is the expectation operator and $\Omega_{t}$ is the information set at time t, when central banks set the target for the interest rate. Thus, the target rate depends both on the expected inflation rate gap and expected output gap.

Clarida et al. $(1998,2000)$ define the ex-ante real interest rate as $r_{t} \equiv i_{t}-E\left(\pi_{t+1} / \Omega_{t}\right)$. Therefore, equation (2) becomes the following:

$$
r_{t}^{*}=\bar{r}+(\beta-1)\left[E\left(\pi_{t+1} / \Omega_{t}\right)-\pi^{*}\right]+\gamma E\left(x_{t} / \Omega_{t}\right),
$$

where $r^{*}$ is the target real interest rate, $\bar{r}$ is the long-run equilibrium real interest rate. In an economy with inflation targeting, $\beta$ plays an important role. If $\beta>1$, then the target real interest rate increases in response to an increase in the expected inflation rate; whereas, if $\beta<1$, then the target real interest rate decreases with an increase in expected inflation. In this latter case, monetary policy proves procyclical. The coefficient $\gamma$, according to economic theory, should exceed zero. These coefficients of the policy rule indicate the weights that central banks set on inflation and output gaps and how the monetary policy responds to changes in inflation and the output gap.

We also assume that the interest rate rule should incorporate interest rate smoothing, which takes the following form:

$$
i_{t}=(1-\rho) i_{t}^{*}+\rho i_{t-1}+u_{t}
$$

where the degree of interest rate smoothing is $\rho$, where $0 \leq \rho \leq 1$, and $u_{t}$ is an exogenous random shock, which follows an i.i.d. process.

Additionally, we redefine the constant in equation (2) as follows:

$$
\alpha \equiv \bar{i}-\beta \pi^{*}
$$

Using equation (5), equation (2) becomes: 


$$
i_{t}^{*}=\alpha+\beta E\left(\pi_{t+1} / \Omega_{t}\right)+\gamma \mathrm{E}\left(x_{t} / \Omega_{t}\right)
$$

Next, incorporating equation (6) into equation (4) yields:

$$
i_{t}=(1-\rho)\left[\alpha+\beta E\left(\pi_{t+1} / \Omega_{t}\right)+\gamma \mathrm{E}\left(x_{/} / \Omega_{t}\right)\right]+\rho i_{t-1}+u_{t} .
$$

Next, rewriting the above equation in terms of realized variables produces:

$$
i_{t}=(1-\rho)\left[\alpha+\beta \pi_{t+1}+\gamma x_{t}\right]+\rho i_{t-1}+\varepsilon_{t},
$$

where $\varepsilon_{t} \equiv-(1-\rho)\left[\beta\left(\pi_{t+1}-E\left(\pi_{t+1} / \Omega_{t}\right)\right)+\gamma\left(x_{t}-\mathrm{E}\left(x_{t} / \Omega_{t}\right)\right)\right]+u_{t}$ is a linear combination of the forecast errors of inflation and the exogenous random shock $u_{t}$. Clarida et al. (1998, 2000) indicate that $u_{t}$ represents a vector of variables the central bank can use in setting the interest rate target and are orthogonal to $\varepsilon_{t}$. That is,

$$
E\left(\varepsilon_{t} / u\right)=0 \Rightarrow E\left(i_{t}-(1-\rho)\left[\alpha+\beta \pi_{t+1}+\gamma x_{t}\right]-\rho i_{t-1} / u_{t}\right)=0 .
$$

We estimate $\alpha, \beta, \gamma$, and $\rho$, using the Generalized Method of Moments (GMM) methodology. The instrument list contains lagged values of inflation, the output gap, and interest rates.

Clarida et al. (1998, 2000) derive the relationship between the target inflation and the long-run equilibrium real interest-rate from coefficients $\beta$ and $\alpha$. In other words, we can determine $\pi^{*}$ as follows:

$$
\pi^{*}=\frac{\bar{r}-\alpha}{\beta-1},
$$

which comes from the following relationships:

$$
\alpha \equiv \bar{i}-\beta \pi^{*} \text { and } \bar{i}=\bar{r}+\pi^{*} \text {. }
$$

Using equation (2) and defining expectations on once-lagged values gives us the backward-looking rule as follows:

$$
i_{t}^{*}=\bar{i}+\beta\left(\pi_{t-1}-\pi^{*}\right)+\gamma x_{t-1},
$$

where $\pi_{t-1}$ and $x_{t-1}$ are the lagged values of the inflation rate and output gap, respectively. As with the forward-looking rule, we can rearrange this rule to derive the rule for the real target 
rate as follows:

$$
r_{t}^{*}=\bar{r}+(\beta-1)\left(\pi_{t-1}-\pi^{*}\right)+\gamma x_{t-1}
$$

After incorporating interest rate smoothing, this rule takes the following form:

$$
i_{t}=(1-\rho)\left[\alpha+\beta \pi_{t-1}+\gamma x_{t-1}\right]+\rho i_{t-1}+u_{t} .
$$

We also use the GMM methodology to estimate the parameters in the backward-looking case.

Finally, we adjust the classic Taylor rule to the European data and find the interest rate target, by adding the interest rate smoothing process to the rule and using current data (Taylor-type rule). The estimating equation is as follows:

$$
i_{t}=(1-\rho)\left[\alpha+\beta \pi_{t}+\gamma x_{t}\right]+\rho i_{t-1}+u_{t}
$$

using the GMM methodology.

\subsection{Inflation and Output Gap Forecasting: Forward-Looking Rule}

This section describes the method that generated the forecasts for the inflation rate and the output gap, which we then use to estimate the forward-looking rule. To generate out-ofsample forecasts, we use a moving window of 72 quarters, starting from 1980Q1 to 1997Q4, to identify the best model and to generate the forecasts for the upcoming sample quarter. We compare three alternative approaches for modeling and forecasting the inflation rate and the output gap: autoregressive integrated moving average (ARIMA) models, vector autoregressive (VAR) models, and the Stock and Watson transfer function model. We use the Theil criterion to select the best model, given the out-of-sample forecasts for each method. In particular, we use a rolling window and estimate all models for each period and select the best model. In other words, using 1980q1-1997q4, we estimate and then forecast one-period ahead, 1998q1. Then, we estimate all models, using 1980q2-1998q1, and forecast 1998:q2. And so on. 
First, we consider the ARIMA(p, d, q) model. That is, we consider the following specification:

$$
\Delta^{d} Y_{t}=\alpha_{1} \Delta^{d} Y_{t-1}+\alpha_{2} \Delta^{d} Y_{t-2}+\ldots+\alpha_{p} \Delta^{d} Y_{t-p}+\beta_{1} u_{t-1}+\ldots+\beta_{q} u_{t-q}
$$

where $Y$ denotes either the inflation rate or the output gap, $p$ denotes the number of autoregressive terms, $d$ denotes the number of differences of the series, and $q$ denotes the number of moving average terms. Both the inflation rate and the output gap are $\mathrm{I}(0)$. Thus, $d$ $=0$. Then we estimate all possible models for $\mathrm{p}, \mathrm{q}:(1, \ldots, 11)$ and using the Akaike information criterion (AIC), we choose the specification with the lowest AIC.

Second, we consider the VAR model's forecasts the inflation rate and the output gap. The estimated VAR models include the following additional variables: the growth rate of $\mathrm{M}_{1}$, the unemployment rate, and the output gap when we forecast the inflation rate, and the growth rate of $\mathrm{M}_{1}$, the unemployment rate, and the inflation rate when we forecast the output gap. Once again, we select the optimal order of VAR using the AIC criterion.

Finally, we consider Stock and Watson (1999) model's forecasts of the inflation rate and the output gap. This transfer function model takes the following form:

$$
Y_{t}=\alpha_{1} Y_{t-1}+\alpha_{2} Y_{t-2}+\ldots+\alpha_{p} Y_{t-p}+\beta_{1} X_{t-1}+\beta_{2} X_{t-2}+\ldots+\beta_{q} X_{t-q}+u_{t}
$$

where $\mathrm{Y}$ is the inflation rate and $\mathrm{x}$ is either the output gap or the unemployment rate. As in the prior two models, we chose the appropriate lag length using the Akaike criterion and estimated the inflation forecasts both in the case of the output gap and in the case of the unemployment rate.

Table 2 reports the results of the analysis, using the Theil criterion to select the best (optimal) forecasting models for each country.

\subsection{The Bank Lending Channel}

The econometric method to investigate the bank lending channel estimates the following baseline equation: 


$$
\begin{aligned}
\Delta \ln L_{i k t}=\alpha_{k} & +\phi_{i k} \Delta \ln L_{i k t-1}+\sum_{j=0}^{n} \beta_{j} \Delta i_{k t-j} \\
& +\sum_{j=0}^{n} \delta_{j} \Delta \ln G D P_{k t-j}+\sum_{j=0}^{n} \omega_{j} \pi_{k t-j}+u_{i k t}
\end{aligned}
$$

where $k=1, \ldots, \mathrm{K}$ and $\mathrm{t}=1, \ldots, \mathrm{T}, k$ denotes the country, $K$ equals six when we estimate the bank lending channel for the Euro-group and one when we estimate the lending channel for Denmark or the United Kingdom, $L_{i k t}$ denotes the loans of the $i^{\text {th }}$ bank of country $k$ in year $t$, $i_{k t}$ denotes the monetary policy indicator of country $k$ in year $t, G D P_{k t}$ denotes the GDP of country $k$ in year $t, \pi_{k t}$ denotes the inflation rate of country $k$ in year t, and $u_{k t}$ denotes the error term.

We use four different monetary policy indicators: the actual short-term interest rate (not coming from a rule) and short-term interest rates that come from the three central bank interest rate rules. That is, this paper examines how loan growth reacts to the actual shortterm interest rate as well as the interest rate target coming out of our forward-looking, backward-looking, and contemporaneous interest rate rules.

In equation (16), we regress the growth rate of a country's lending $(\Delta \ln L)$ on the real GDP growth rate $(\triangle \ln G D P)$ and on the inflation rate $(\pi)$ to control for country-specific loan demand changes due to macroeconomic activity. In other words, we isolate shifts in total loans caused by movements in loan demand to identify the supply relationship. The introduction of these two variables also proves important because it isolates the monetary policy indicator, the short-term interest rate and the target interest rates from our three policy rules. Additionally, we include lagged values of the dependent variable, because lagged loans affect current loans in an environment where banks establish continuing relationships with their customers. In other words, the bank acquires "informational monopoly over its clients.” Hence, customers encounter large costs to change their banks, because new banks will need to collect costly information about its new customers in the provision of banking services (Golodniuk, 2006). Monetary policy also affects lending with lags, due to long-term 
contractual commitments. According to the bank lending channel, the negative coefficient on the interest rate causes loans to fall after a monetary tightening. We estimate the model using the panel GMM estimator, suggested by Arellano and Bond (1991), where we only include statistically significant lags in the estimation.

\subsubsection{Bank-Specific Characteristics}

In addition to the baseline model, we also construct a similar model designed to test whether banks with different characteristics react differently to a monetary shock. This model takes the following form:

$$
\begin{aligned}
\Delta \ln L_{i k t}= & a_{k}+\varphi_{i k} \Delta \ln L_{i k t-1}+\sum_{j=0}^{n} \beta_{j} \Delta i_{k t-j}+\sum_{j=0}^{n} \delta_{j} \Delta \ln G D P_{k t-j} \\
& +\gamma_{i k} B S_{i k t-1}+\sum_{j=0}^{n} \lambda_{j} \Delta i_{k t-j} B S_{i k t-1}+u_{i k t} .
\end{aligned}
$$

This equation differs from equation (16), because it incorporates two additional terms - a bank-specific characteristic and its interaction with the monetary policy indicator. More specifically, we introduce three separate bank-specific characteristics $\left(B S_{i k}\right)$-- bank capitalization, asset size, and liquidity -- and the interaction terms $\left(\Delta i_{k t-j} B S_{i k t-1}: j=1, \ldots, n\right)$. The monetary authority chooses either the short-term interest rate or the target short-term interest rates derived by the policy rules described above. Following Gambacorta (2005), we define the $B S_{i k}$ as deviations from their respective means. Thus, the effect of the $B S_{i k}$ on the growth rate of lending evaluated at the mean of the $B S_{i k}$ equals $\gamma_{i k}$.

\subsubsection{Robustness Tests}

We also examine the robustness of the results concerning the bank lending channel, excluding the bank-specific characteristics. As noted previously, we control for demand effects using two particular variables - the real GDP growth rate and the inflation rate. In this specification, we consider alternative control variables as a robustness check. First, we replace the real GDP growth rate and the inflation rate with the growth rate of real 
consumption spending. Now, equation (16) takes the following form:

$$
\Delta \ln L_{i k t}=a_{k}+\varphi_{i k} \Delta \ln L_{i k t-1}+\sum_{j=0}^{n} \beta_{j} \Delta i_{k t-j}+\sum_{j=0}^{n} \delta_{j} \Delta \ln \operatorname{Con}_{k t-j}+u_{i k t},
$$

where Con is real consumption spending. Similar to equation (16), the bank lending channel operates when the monetary policy indicator affects loan supply negatively. In this case, we isolate changes in total loans caused by movements in loan demand by the private consumption. Thus, for changes in consumption, we expect a positive coefficient.

Second, we also substitute for the inflation rate in equation (18), in turn, the ratio of total loans to total deposits and then total deposits. Growth in loan demand may cause banks to issue more insured deposits. Absent informational asymmetries, banks can obtain funding both from internal (insured deposits) and external (noninsured deposits) sources. Due to the absence of perfect information, however, banks exhibit different attitudes toward different sources of funding. In other words, the presence of such frictions links deposits and lending, causing them to move together because a growing demand for loans generates faster growth in deposits. An increasing loan-to-deposit ratio, because of loan demand growth, may force banks to search, in addition to insured deposits, for additional reserves, and, therefore, they may use more non-deposit funding to finance the presence of higher demand for loans (Jayaratne and Morgan, 1997; Juks, 2004). Thus, the 'new' model, when we include the ratio of total loans to total deposits, yields:

$$
\begin{gathered}
\Delta \ln L_{i k t}=a_{k}+\varphi_{i k} \Delta \ln L_{i k t-1}+\sum_{j=0}^{n} \beta_{j} \Delta i_{k t-j}+\sum_{j=0}^{n} \delta_{j} \Delta \ln G D P_{k t-j} \\
+\sum_{j=0}^{n} \gamma_{j} \ln \left(L / D e p_{i k t-j}\right)+u_{i k t}
\end{gathered}
$$

where $L / D e p$ equals the ratio of total loans to total deposits. In this case, we expect a positive coefficient on this ratio in that an increase in the ratio causes an increase in bank lending,

When we include total deposits as an additional variable to control for loan demand, the model takes the following form: 


$$
\begin{gathered}
\Delta \ln L_{i k t}=a_{k}+\varphi_{i k} \Delta \ln L_{i k t-1}+\sum_{j=0}^{n} \beta_{j} \Delta i_{k t-j}+\sum_{j=0}^{n} \delta_{j} \Delta \ln G D P_{k t-j} \\
+\sum_{j=0}^{n} \gamma_{j} \Delta \ln \left(D e p_{i k t-j}\right)+u_{i k t}
\end{gathered}
$$

where Dep equals total deposits. In this last case, we also expect a positive coefficient, since when the growth of total deposits increase, bank reserves grow a well, leading to increases in the growth of loans.

\section{Empirical Analysis}

\subsection{Interest Rate Rules Results}

Table 3 reports the results of estimating the three interest rate rules for the Euro-group, Denmark, and the U.K. The estimates of the coefficients for the backward-looking, Taylor, and forward-looking rules tell a consistent story within and across the Eurogroup, Denmark, and the U.K. An activist monetary policy that stabilizes the macroeconomy requires a $\beta$ coefficient, (i.e., the coefficient on the inflation gap) that exceeds one. At the same time, the $\gamma$ coefficient (i.e., the coefficient on the output gap) should also exceed zero, but with no size requirement. In all rules and countries, the coefficient of the inflation gap exceeds one and the coefficient of the output gap exceeds zero, albeit by a small amount. The Eurogroup, Denmark, and the UK respond vigorously to the inflation gap, especially for the backwardlooking model. In addition, Denmark responds the most to the output gap and the U.K. the least. Interest rate smoothing plays an important role in each country, and plays the largest role in the U.K. The J-statistics imply that we cannot reject the over identifying restrictions of the models. Our findings show $\beta$ coefficients that uniformly exceed those reported in Apergis and Alevizopoulou (2012), suggesting a more aggressive anti-inflation central bank policy response. In fact, Apergis and Alevizopoulou report that the Taylor rule and the forwardlooking rule in the UK exhibit a $\beta$ coefficient that falls below one, indicating a procyclical monetary policy response to increases in inflation as the real interest rate actually rises with 
inflation.

\subsection{Bank Lending Channel Results}

We report the results for the bank lending channel in Tables 4 to 10. We estimate the models using the panel GMM estimator and the Sargan test indicates valid instruments in all cases. The entries in all tables include the coefficients of the variables and their corresponding pvalues estimated for the Eurogroup, Denmark, and the UK by introducing the four different indicators for the estimation of the bank lending channel. In all Tables, columns 1 and 2 report the findings when we include the European Central Bank (ECB) interest rate in the model for the estimation of the bank lending channel (Model I). Then, columns 3 and 4, 5 and 6, and 7 and 8 record the results when we include the target interest rate derived from the backward-looking rule (Model II), the target interest rate from the Taylor-type rule (Model III), and the target interest rate from the forward-looking rule (Model IV), respectively.

The findings for the annual growth rate of lending in the benchmark model expressed in equation (16) appear in Table 4. The coefficients of the monetary policy indicator, showing the effects of the decisions of monetary policy on lending, exhibit the expected negative sign in all four models and for all countries and prove significant at the 5-percent level in each case. This implies that higher interest rates - actual or target - induce lower loan growth. The findings identify the highest effect for the forward-looking rule and the smallest effect for the actual interest rate, except for Denmark and the UK, where the Taylor-rule interest rate exerts the largest and smallest effects, respectively. The Taylor-rule interest rate exerts its influence contemporaneously whereas the other interest rates generally exert their influence with a lag.

Table 4 also reports the coefficients and their corresponding p-values for the real GDP growth rate and the inflation rate, respectively, for the four models and the three countries. The coefficients of real GDP growth exhibit positive and statistically significant effects in all models and for all countries. The coefficients of the inflation rate generally show a positive 
effect, when significant, except for the significant negative effect for the actual and forwardlooking interest rate in Denmark. The inflation coefficient proves insignificant at the 5percent level in the UK, except for the Taylor-rule model where this coefficient is significantly positive.

Overall, the empirical analysis for equation (16) indicates that the bank lending channel operates better if the target interest rate comes from the forward-looking rule, if one considers the magnitude of the effect. These conclusions match those reported in Apergis and Alevizopoulou (2012). If the policy maker wants a quicker response, then the Taylor-rule interest rate response dominates the other interest rates, a finding that Apergis and Alevizopoulou (2012) do not consider in their model specification.

\subsection{Results with Bank-Specific Characteristics}

Table 5, 6, and 7 present the results for the bank lending channel from the estimation of equation (17), which, in addition to lagged loans, the monetary policy indicator, and the real GDP growth rate, includes, in turn, two additional terms -- bank-specific characteristics and the interaction terms each bank-specific characteristic and the change in the monetary indicator. Note, however, that equation (17) excludes the inflation rate. ${ }^{2}$ Thus, the results, presented in Tables 5, 6, and 7, use only the real GDP growth rate to control for demand effects.

Tables 5, 6, and 7 report the coefficients of the parameters in equation (17) for bank capitalization, size, and liquidity, respectively. Guiso et al. (2002) find that proxies for banks' health, such as size, capitalization, efficiency, and liquidity, provide useful instruments for the interest rate that banks charge on their loans, while Altunbas et al. (2009) confirm the hypothesis that bank characteristics represent key drivers of banks' ability to supply new

\footnotetext{
${ }^{2}$ We also estimated models that included the inflation rate, but its coefficient never proved significant and, thus, we exclude those results from our reported findings. Moreover, the inclusion or exclusion of the inflation rate does not alter the sign and significance of any of the other coefficients.
} 
loans. When controlling for bank specific characteristics, monetary policy affects the growth of lending negatively across all specifications and countries and usually the effect proves significant at the 5-percent level. The exceptions include insignificant effects for the current interest rate for the UK with size as the bank-specific effect, for the backward-looking and Taylor rules for the Eurogroup with size as the bank-specific effect, for the forward-looking rule for Denmark with liquidity as the bank-specific effect, and for the current interest rate in the Eurogroup and the UK with liquidity as the bank-specific effect,.

The growth rate of real GDP proves positive, whenever the coefficient proves significant at the 5-percent level. Three instances occur where the positive coefficient on the growth rate of real GDP is not significant - all with positive signs.

The bank-specific variables lead to the following outcomes when we consider the effects of $B S_{i k}$ at their mean value. Higher bank capitalization or bigger banks associate with higher lending growth whenever the coefficient is significant (see Table 5). Larger banks associate with significantly more bank lending, except in two cases (see Table 6). These exceptions, where larger banks significantly associate with lower bank lending, occur for the UK when using the Taylor and forward-looking rules. More liquid banks associate with significantly more bank lending in all cases (see Table 7), except for Denmark with the forward-looking rule.

When we consider the interaction terms in conjunction with the interest rate effects, we find the following results. More capitalized banks associate with a smaller bank lending effect, since all coefficients of the interaction terms prove positive and significant except in three cases (see Table 5). Two significant exceptions occur in the UK for the current interest rate and the forward-looking rule. In these two cases, more capitalized banks exhibit higher bank lending, since the coefficients are significantly negative. Larger banks also exhibit a significantly smaller bank lending effect in most cases (see Table 6). But, the Eurogroup 
experiences a larger bank-lending effect for the backward-looking rule and Denmark experiences a larger bank-lending effect for the current interest rate. Focusing on significant coefficients, more liquid banks associate with a significantly smaller bank lending effect, except for the UK and with backward-looking and Taylor rules (see Table 7).

\subsection{Robustness Tests}

Table 8 reports the results of replacing the growth rate of real GDP with the growth rate of real consumption spending whereas Tables 9 and 10 use loans to deposits and the growth rate of deposits in equation (19) and (20), respectively, as robustness checks. Once again, the monetary policy variable exhibits a negative effect wherever the coefficient proves significant at the 5-percent level in all cases in Tables 8, 9, and 10. In Table 8, the growth rate of real consumption spending exhibits a significant positive effect on the growth rate of lending in every case. In Tables 9 and 10, the growth rate of real GDP produces a significant positive effect on the growth rate of lending, except for the Eurogroup when we include the ratio of total loans to total deposits and the UK when we include the growth rate of deposits both using the Taylor-rule target interest rate. In Table 9, a higher ratio of loans to deposits generates a positive effect on the growth rate of lending, wherever the coefficient is significant, except for Denmark, in the case of the backward-looking rule. In Table 10, a larger growth rate of deposits generates a significant positive effect on the growth rate of lending, except for Denmark using the forward-looking rule target interest rate.

\section{Conclusions}

Interest rate rules now command significant attention amongst economists and policymakers, since they provide a structure within which to analyze the behavior of central banks. The bank lending channel also commands significant attention as well, because its operation provides an alternative channel whereby the monetary authorities' decisions can affect the real economy by altering the supply of bank loans. 
In this paper, we estimate three types of interest rate rules -- backward-looking, contemporaneous (Taylor-type), and forward-looking rules. We estimate these interest rate rules for three economies: the Euro-group, which consists of selected European countries with the Euro as a common currency, Denmark, and the UK over the period 2000 to 2009. We use these estimates in the second part of the paper to examine the bank lending channel in these economies under four scenarios concerning the interest rate used as a monetary policy indicator -- the central bank interest rate and the three different interest rate targets derived from the backward-looking, Taylor, and forward-looking rules.

The bank-lending channel exists in all cases, but differences emerge in the degrees of responsiveness of loan growth to changes in the monetary policy indicator. Thus, the banklending channel exerts a stronger effect when we use target rates as indicators rather than the observed central bank interest rates. The strongest effects generally emerge in the models employing the forward-looking rules. This suggests that the monetary authorities use target interest rate rules, especially a forward-looking rule as the monetary policy indicator. That is, forward-looking rules incorporate inflationary expectations that seem to affect the decisions for the target rate and, hence, for monetary policy. Monetary policy guides, through its actions and announcements, the private sector's (banks') expectations. Therefore, banking institutions alter their supply of loans according to the rules, making monetary policy decisions more effective.

This paper also examines whether lending differentials depend on the strength of a bank, characterized by capitalization, asset size, and liquidity. Furthermore, we also account for additional variables, in addition to real GDP growth, in the estimation of the bank lending channel. We use the growth rate of real consumption spending, the ratio of total loans to total deposits, and the growth rate of deposits as additional control variables. The results indicated that large and well-capitalized banks more easily absorb monetary shocks. In most of the 
cases, the bank lending channel strengthens when we use target rates derived from interest rate rules and, specifically, from the forward-looking rule as the monetary policy indicator, a conclusion that strengthens our initial results.

Our empirical findings also show that the significance of the bank lending channel under all alternative monetary policy rules signals the inability of European banks to issue unlimited amounts of CDs or bonds not subject to reserve requirements. Moreover, the same banks cannot easily issue new equity due to the presence of tax disadvantages, adverse selection problems, and agency costs.

Our empirical findings highlight the role of the banking sector in providing credit to the real economy, which became important in the recent global financial crisis. Within such a distressed financial environment, changes in bank lending terms should become an explicit component of macroeconomic models that describe monetary policy rules used for policy advice, especially Dynamic Stochastic General Equilibrium (DSGE) models. At the same time, the effects of financial innovations on the transmission mechanism of monetary policy should feed the need for more intensive financial supervision.

Finally, our empirical analysis abstracts from the zero lower bound (ZLB) hypothesis on nominal interest rates, a hypothesis asserting that central banks cannot lower the interest rate in the face of a weak economy and low inflation, which can impair the effectiveness of monetary policy to stabilize output and inflation (Williams, 2009). Therefore, future empirical attempts will modify our alternative policy rules to account for the ZLB environment. 


\section{References}

Altunbas, Y., Gambacorta, L., \& Marques-Ibanez, D., (2009). Securitization and the bank lending channel. European Economic Review 53, 996-1009.

Apergis, N., \& Alevizopoulou, E., (2012). The bank lending channel and monetary policy rules: Evidence from European banks. International Advances in Economic Research 18, 1-14.

Arellano, M., \& Bond, S., (1991). Some tests of specification for panel data: Monte Carlo evidence and an application to employment equations. Review of Economic Studies $58,277-297$.

Brissimis, S. N., Kamberoglou, N. C., \& Simigiannis, G. T., (2001). Is there a bank lending channel of monetary policy in Greece? Evidence from bank level data. European Central Bank, Working Paper Series, Working Paper No. 104.

Clarida, R., Gali J., \& Gertler, M., (1998). Monetary policy rules in practice: Some international evidence. European Economic Review 42, 1033-1067.

Clarida, R., Gali, J., \& Gertler, M., (2000). Monetary policy rules and macroeconomic stability: evidence and some theory. Quarterly Journal of Economics 115, 147-180.

Disyatat, P., (2011). The bank lending channel revisited. BIS Working Paper, No. 297. Bank for International Settlements, Basel, Switzerland.

Ehrmann, M., Gambacorta, L., Martinez-Pages, J., Sevestre, P., \& Worms, A., (2003). Financial systems and the role of banks in monetary policy transmissions in the euro area. In: Angeloni, I., Kashyap, A., \& Mojon, B., (Eds.), Monetary Policy Transmission in the Euro Area. Cambridge: Cambridge University Press.

Fendel, R. M., \& Frenkel, M. R., (2006). Five years of single European monetary policy in practice: Is the ECB rule-based? Contemporary Economic Policy 24, 106-115.

Fourcans, A., \& Vranceanu, R., (2004). The ECB interest rate rule under the Duisenberg presidency. European Journal of Political Economy 20, 579-595.

Gambacorta, L., (2005). Inside the bank lending channel. European Economic Review 49, 1737-1759.

Gerdesmeier, D., \& Roffia, B., (2003). Empirical estimates of reaction function for the Euro area. European Central Bank, Working Paper Series, Working Paper No 206.

Golodniuk, I., (2006). Evidence on the bank lending channel in Ukraine. Research in International Business and Finance 20, 180-199.

Greenspan, A., (1997). Rules versus discretionary monetary policy. Remarks at the $15^{\text {th }}$ Anniversary Conference of the Center for Economic Policy Research at Stanford University. Stanford, CA. 
Guiso, L., Kashyap, A., Panetta, F., \& Terlizzese, D., (2002). How interest sensitive is investment? Very (when the data are well measured). Paper presented at the NBER Summer Institute, Capital Markets in the Economy Workshop. http://www.nber.org/ confer/2002/si2002/guiso.pdf.

Haldane, A., \& Batini, N., (1999). Forward-looking rules for monetary policy. In: Taylor J. B., (Ed.), Monetary Policy Rules, University of Chicago Press, Chicago.

Hayo, B., \& Hofmann, B., (2005). Monetary policy reaction functions: ECB versus Bundesbank. Marburg Papers on Economics, No. 02-2005, Marburg.

Hernando, I., \& Pages, J. M., (2001). Is there a bank lending channel of monetary policy in Spain? European Central Bank, Working Paper Series, Working Paper No. 99.

Jayaratne, J., \& Morgan, D., (1997). Information problems and deposit constraints at banks. Federal Reserve Bank of New York, Research Paper No 9731.

Juks, R., (2004). The importance of the bank-lending channel in Estonia: Evidence from micro-economic data. Working papers of Eesti Pank, Working paper No 6.

Juurikkala, T., Karas, A., \& Solanko, L., (2011). The role of banks in monetary policy transmission: empirical evidence from Russia. Review of International Economics 19, 109-121.

Kashyap, A. K., Stein, J. C., \& Wilcox, D. W., (1993). Monetary policy and credit conditions: evidence from the composition of external finance. American Economic Review 83, 78-98.

Kishan, R. P., \& Opiela, T. P., (2000). Bank size, bank capital and the bank lending channel. Journal of Money, Credit and Banking 32, 121-141.

Kozichi, N., (1999). How useful are Taylor rules for monetary policy? Federal Reserve Bank of Kansas, Economic Review 2, 5-33.

Levin, A. T., Wieland, V., \& Williams, J. C., (1999). Robustness of simple monetary policy rules under model uncertainty. In: Taylor, J. N., (Ed.) Monetary Policy Rules. Chicago: Chicago University Press.

Meyer, L. H., (2002). Rules and discretion: remarks at the Owen Graduate School of Management. Vanderbilt University, Nashville, TN.

Oliner, S. D., \& Rudenbusch, G. D., (1995). Is there a bank lending channel for monetary policy? Federal Reserve Bank of San Francisco, Economic Review 2, 1-22.

Orphanides, A., (2001). Monetary policy rules based on real-time data. American Economic Review 91, 964-985.

Orphanides, A., (2003). Historical monetary policy analysis and the Taylor rule. Journal of Monetary Economics 50, 983-1022. 
Peek, J., \& Rosengren, E. S., (1995). Bank lending and the transmission of monetary policy. In: Peek, J., and Rosengren, E. S., (Eds.), Is Bank Lending Important for the Transmission of Monetary Policy? Federal Reserve Bank of Boston Conference Series, No 39, 47-68.

Rudebusch G. D., (2002). Term structure evidence on interest rate smoothing and monetary policy inertia. Journal of Monetary Economics 49, 1161-1187.

Stock, H. J. \& Watson, W. M., (1999). Forecasting inflation. NBER Working Paper Series, Working paper No 7023.

Taylor, J. B., (1993). Discretion versus policy rules in practice. Carnegie-Rochester Conference Series on Public Policy 39, 195-214.

Taylor ,J. B., (1999). The robustness and efficiency of monetary policy rules as guidelines for interest rate setting by the European central bank. Journal of Monetary Economics 43, 655-679.

Williams, J. C., (2009). Heeding Daedalus: Optimal inflation and the zero lower bound. Brookings Papers on Economic Activity Fall, 1-37.

Woodford, M., (1999). Optimal policy inertia. Manchester School, Supplement 67, 1-35. 
Table 1: $\quad$ Number of banks in each country

\begin{tabular}{lc}
\hline Country & Number of banks \\
\hline Austria & 68 \\
Belgium & 16 \\
Finland & 2 \\
France & 94 \\
Germany & 475 \\
Netherlands & 3 \\
Denmark & 59 \\
United Kingdom & 22 \\
\hline Total & 739 \\
\hline \hline
\end{tabular}

Table 2: $\quad$ Models to Forecast the Inflation Rate and the Output Gap

\begin{tabular}{|l|c|c|}
\hline Country & Inflation Rate Model & Output Gap Model \\
\hline Eurogroup & $\begin{array}{c}\text { Stock \& Watson (with } \\
\text { unemployment rate) }\end{array}$ & ARIMA \\
\hline Denmark & $\begin{array}{c}\text { Stock \& Watson (with } \\
\text { unemployment rate) }\end{array}$ & $\begin{array}{c}\text { Stock \& Watson (with } \\
\text { unemployment rate) }\end{array}$ \\
\hline UK & ARIMA & $\begin{array}{c}\text { Stock \& Watson (with } \\
\text { unemployment rate) }\end{array}$ \\
\hline
\end{tabular}

Table 3: $\quad$ Interest rate rule results for Eurogroup, Denmark, and the United Kingdom

\begin{tabular}{lccccccc}
\hline & $\boldsymbol{\alpha}$ & $\boldsymbol{\beta}$ & $\boldsymbol{\gamma}$ & $\boldsymbol{\rho}$ & $\begin{array}{c}\text { Adj. R- } \\
\text { squared }\end{array}$ & J-stat & Prob. \\
\hline Eurogroup & & & & & & & \\
Backward & 0.0130 & 3.1828 & 0.0003 & 0.5878 & 0.7545 & 0.0930 & 0.2719 \\
Taylor & 0.0163 & 2.7876 & 0.0005 & 0.6013 & 0.8948 & 0.0000 & 1.0000 \\
Forward & 0.0220 & 1.6987 & 0.0009 & 0.2653 & 0.7351 & 0.0000 & 1.0000 \\
Denmark & & & & & & & \\
Backward & 0.0085 & 3.9951 & 0.0011 & 0.6738 & 0.7358 & 0.0000 & 1.0000 \\
Taylor & 0.0199 & 1.8000 & 0.0033 & 0.6663 & 0.8474 & 0.0000 & 1.0000 \\
Forward & 0.0198 & 2.1812 & 0.0045 & 0.6218 & 0.8390 & 0.1123 & 0.1452 \\
U.K. & & & & & & & \\
Backward & 0.0308 & 2.5192 & 0.0001 & 0.8796 & 0.8547 & 0.0636 & 0.3838 \\
Taylor & 0.0382 & 1.2969 & 0.0001 & 0.8571 & 0.8992 & 0.0325 & 0.6682 \\
Forward & 0.0356 & 2.8948 & 0.0001 & 0.8743 & 0.8524 & 0.0762 & 0.3009 \\
\hline \hline
\end{tabular}

Notes: Backward-looking, Taylor-type, and forward-looking rules are given by the following equations, respectively:

$$
\begin{aligned}
& i_{t}=(1-\rho)\left[\alpha+\beta \pi_{t-1}+\gamma x_{t-1}\right]+\rho i_{t-1}+u_{t} \\
& i_{t}=(1-\rho)\left[\alpha+\beta \pi_{t}+\gamma x_{t}\right]+\rho i_{t-1}+u_{t} \\
& i_{t}=(1-\rho)\left[\alpha+\beta E\left(\pi_{t+1} / \Omega_{t}\right)+\gamma \mathrm{E}\left(x_{/} / \Omega_{t}\right)\right]+\rho i_{t-1}+u_{t}
\end{aligned}
$$

where $\alpha$ is a constant, reflecting the changes in the inflation target and the equilibrium real interest rate, $\pi=$ the inflation gap, $\mathrm{x}=$ the output gap and $\rho=$ the interest rate smoothing parameter. We estimate the models using the GMM methodology. The J-statistics implies that we cannot reject the null hypothesis of over identifying restrictions. 
Table 4: $\quad$ The bank lending channel results for the Eurogroup, Denmark, and the United Kingdom

\begin{tabular}{|c|c|c|c|c|c|c|c|c|}
\hline \multirow[b]{3}{*}{ Eurogroup } & \multicolumn{8}{|c|}{ Dependent variable: Annual growth rate of lending } \\
\hline & \multicolumn{2}{|c|}{$\begin{array}{c}\text { Monetary policy } \\
\text { indicator: } \\
\text { ECB rate } \\
\text { (Model I) } \\
\end{array}$} & \multicolumn{2}{|c|}{$\begin{array}{c}\text { Monetary policy } \\
\text { indicator: } \\
\text { Backward rule } \\
\text { (Model II) } \\
\end{array}$} & \multicolumn{2}{|c|}{$\begin{array}{c}\text { Monetary policy } \\
\text { indicator: } \\
\text { Taylor rule } \\
\text { (Model III) } \\
\end{array}$} & \multicolumn{2}{|c|}{$\begin{array}{c}\text { Monetary policy } \\
\text { indicator: } \\
\text { Forward rule } \\
\text { (Model IV) } \\
\end{array}$} \\
\hline & Coef. & Prob & Coef. & Prob & Coef. & Prob & Coef. & Prob \\
\hline$\Delta i_{k t}$ & & & & & -0.9710 & 0.0010 & & \\
\hline$\Delta i_{k t-1}$ & -0.5994 & 0.0237 & -1.0895 & 0.0037 & & & -3.3783 & 0.0000 \\
\hline$\Delta \ln G D P_{k t}$ & & & 0.2806 & 0.0357 & 0.4712 & 0.0004 & & \\
\hline$\Delta \ln G D P_{k t-1}$ & 0.1055 & 0.0002 & & & & & 0.2252 & 0.0000 \\
\hline$\pi_{k t}$ & & & & & 2.1265 & 0.0361 & & \\
\hline$\pi_{k t-1}$ & -0.8394 & 0.3707 & 1.2003 & 0.0196 & & & 1.9916 & 0.0002 \\
\hline Denmark & Coef. & Prob & Coef. & Prob & Coef. & Prob & Coef. & Prob \\
\hline$\Delta i_{k t-1}$ & & & -0.8508 & 0.0000 & -1.2620 & 0.0000 & & \\
\hline$\Delta i_{k t-2}$ & -0.6628 & 0.0000 & & & & & -1.0087 & 0.0000 \\
\hline$\Delta \ln G D P_{k t-1}$ & 0.4532 & 0.0000 & & & 0.7084 & 0.0000 & 4.6166 & 0.0000 \\
\hline$\Delta \ln G D P_{k t-2}$ & & & 0.3057 & 0.0000 & & & & \\
\hline$\pi_{k t}$ & & & & & 2.5152 & 0.0000 & & \\
\hline$\pi_{k t-1}$ & -1.6048 & 0.0000 & 0.9205 & 0.0000 & & & -16.8969 & 0.0000 \\
\hline U.K. & Coef. & Prob & Coef. & Prob & Coef. & Prob & Coef. & Prob \\
\hline$\Delta i_{k t}$ & & & & & -0.8684 & 0.0000 & & \\
\hline$\Delta i_{k t-1}$ & -0.8903 & 0.0472 & -1.4195 & 0.0000 & & & & \\
\hline$\Delta i_{k t-2}$ & & & & & & & -11.9038 & 0.0085 \\
\hline$\Delta \ln G D P_{k t}$ & & & 1.1908 & 0.0000 & 0.3693 & 0.0000 & & \\
\hline$\Delta \ln G D P_{k t-1}$ & 0.8808 & 0.0000 & & & & & 1.2709 & 0.0051 \\
\hline$\pi_{k t}$ & -6.1414 & 0.0858 & 1.0730 & 0.2896 & 2.8665 & 0.0001 & -2.4020 & 0.6047 \\
\hline
\end{tabular}

Note: Coefficient and p-value estimates for the group of European countries, Denmark, and the United Kingdom, according to the four models that use different monetary policy indicators. Bolded coefficients prove significant at the 5-percent level. The models are given by the following equation:

$$
\Delta \ln L_{i k t}=a_{k}+\varphi_{i k} \Delta \ln L_{i k t-1}+\sum_{j=0}^{n} \beta_{j} \Delta i_{k t-j}+\sum_{j=0}^{n} \delta_{j} \Delta \ln G D P_{k t-j}+\sum_{j=0}^{n} \omega_{j} \pi_{k t-j}+u_{i k t}
$$

with $\mathrm{k}=1, \ldots, \mathrm{K}$, where $k$ denotes the country and $K=6$ for the group of European countries and $K=1$ for Denmark and the United Kingdom, $\mathrm{t}=1, \ldots \mathrm{T}, L_{i k t}$ denotes the loans of the $i^{\text {th }}$ bank of country $k$ in year $t$, $i_{k t}$ denotes the monetary policy indicator of country $k$ in year $t, G D P_{k t}$ denotes the GDP of country $k$ in year $t, \pi_{k t}$ denotes the inflation rate of country $k$ in year $t$, and $u_{k t}$ denotes the error term. The monetary policy indicator takes four forms: in Model I: the actual short-term interest rate (not coming from a rule) and in Models II to IV: the interest rate target coming out of our backward-looking, Taylor-type, and forward-looking rule, respectively. We estimate the models using the GMM estimator suggested by Arellano and Bond (1991). For the Eurogroup, instruments include the first lag in Model III, and the second lag in the rest of the models for the monetary policy indicator and inflation, whereas for the real GDP growth rate the first lag in Models II and III and the second lag in Models I and IV. For Denmark, instruments include the second lag in Models II and III, and the third lag in Models I and IV for the monetary policy indicator. We use the second lag as an instrument for the real GDP growth rate in Models I, III, and IV, whereas in Model II, we use the third lag. For inflation, we use the first lag as an instrument in Models III and IV and the second lag in the rest of the Models. In the UK case, instruments for the monetary policy indicator include the first lag in Model III, the second lag in Models I and II, and the third lag in Model IV. We use the first lag as an instrument for the real GDP growth rate in Models II and III and the second lag in the rest of the models. Finally, we use the first lag as an instrument for inflation. We use the second lag as an instrument for the lagged loans in all cases. 
Table 5: $\quad$ The bank lending channel results for the Eurogroup, Denmark, and the United Kingdom, including capitalization as bank-specific characteristic

\begin{tabular}{|c|c|c|c|c|c|c|c|c|}
\hline \multirow[b]{3}{*}{ Eurogroup } & \multicolumn{8}{|c|}{ Dependent variable: Annual growth rate of lending } \\
\hline & \multicolumn{2}{|c|}{$\begin{array}{c}\text { Monetary policy } \\
\text { indicator: } \\
\text { ECB rate } \\
\text { (Model I) }\end{array}$} & \multicolumn{2}{|c|}{$\begin{array}{c}\text { Monetary policy } \\
\text { indicator: } \\
\text { Backward rule } \\
\text { (Model II) } \\
\end{array}$} & \multicolumn{2}{|c|}{$\begin{array}{c}\text { Monetary policy } \\
\text { indicator: } \\
\text { Taylor rule } \\
\text { (Model III) } \\
\end{array}$} & \multicolumn{2}{|c|}{$\begin{array}{l}\text { Monetary policy } \\
\text { indicator: } \\
\text { Forward rule } \\
\text { (Model IV) }\end{array}$} \\
\hline & Coef. & $\underline{\text { Prob }}$ & Coef. & Prob & Coef. & Prob & Coef. & Prob \\
\hline$\Delta i_{k t-1}$ & -0.9600 & 0.0060 & -3.8256 & 0.0011 & -1.7250 & 0.0003 & -5.2451 & 0.0000 \\
\hline$\Delta \ln G D P_{k t-1}$ & 0.3310 & 0.0131 & 0.5238 & 0.0002 & 0.7269 & 0.0726 & 0.6581 & 0.0000 \\
\hline $\operatorname{Cap}_{i k t-1}$ & 0.0261 & 0.0000 & 0.0165 & 0.2766 & 0.0405 & 0.0000 & 0.0761 & 0.0000 \\
\hline$\Delta i_{k t-1} * \operatorname{Cap}_{i k t-1}$ & 4.1960 & 0.0129 & 19.5085 & 0.0029 & 5.4612 & 0.0001 & 32.3149 & 0.0000 \\
\hline Denmark & Coef. & Prob & Coef. & Prob & Coef. & Prob & Coef. & Prob \\
\hline$\Delta i_{k t}$ & & & -1.3787 & 0.0000 & & & -3.7975 & 0.0000 \\
\hline$\Delta i_{k t-1}$ & & & & & -14.5588 & 0.0000 & & \\
\hline$\Delta i_{k t-2}$ & -1.4175 & 0.0000 & & & & & & \\
\hline$\Delta \ln G D P_{k t-1}$ & 3.3882 & 0.0000 & 4.6323 & 0.0000 & 9.5442 & 0.0000 & 4.7153 & 0.0000 \\
\hline Cap $_{i k t}$ & & & & & & & 0.0230 & 0.0000 \\
\hline Cap $_{\text {ikt-1 }}$ & 0.0041 & 0.1499 & 0.0103 & 0.0000 & -0.0022 & 0.0931 & & \\
\hline$\Delta i_{k t} * C a p_{i k t}$ & & & & & & & 5.7402 & 0.0000 \\
\hline$\Delta i_{k t} * C a p_{i k t-1}$ & & & 5.8059 & 0.0000 & & & & \\
\hline$\Delta i_{k t-1} * C a p_{i k t-1}$ & & & & & 7.9525 & 0.0000 & & \\
\hline$\Delta i_{k t-2} * C a p_{i k t-1}$ & 4.8895 & 0.0000 & & & & & & \\
\hline U.K. & Coef. & $\underline{\text { Prob }}$ & Coef. & Prob & Coef. & Prob & Coef. & Prob \\
\hline$\Delta i_{k t-1}$ & & & -16.7576 & 0.0000 & & & & \\
\hline$\Delta i_{k t-2}$ & -1.9468 & 0.0482 & & & -23.6321 & 0.0173 & -10.7103 & 0.0000 \\
\hline$\Delta \ln G D P_{k t}$ & & & 1.2604 & 0.0000 & & & & \\
\hline$\Delta \ln G D P_{k t-1}$ & 0.1165 & 0.8741 & & & 0.8981 & 0.0009 & 1.3704 & 0.0000 \\
\hline $\operatorname{Cap}_{i k t}$ & & & & & & & -0.0054 & 0.6775 \\
\hline Cap $_{\text {ikt-1 }}$ & 0.0131 & 0.4688 & 0.0370 & 0.0341 & 0.0137 & 0.2835 & & \\
\hline$\Delta i_{k t-1} * \operatorname{Cap}_{i k t-1}$ & & & 7.6316 & 0.0035 & & & & \\
\hline$\Delta i_{k t-2} * C a p_{i k t}$ & & & & & & & -17.6760 & 0.0000 \\
\hline$\Delta i_{k t-2} * \operatorname{Cap}_{i k t-1}$ & -13.2636 & 0.0000 & & & 1.3753 & 0.9369 & & \\
\hline
\end{tabular}

Note: $\quad$ See Table 4 . The models are given by the following equation:

$$
\Delta \ln L_{i k t}=a_{k}+\varphi_{i k} \Delta \ln L_{i k t-1}+\sum_{j=0}^{n} \beta_{j} \Delta i_{k t-j}+\sum_{j=0}^{n} \delta_{j} \Delta \ln G D P_{k t-j}+\gamma_{i k} B S_{i k t-1}+\sum_{j=0}^{n} \lambda_{j} \Delta i_{k t-j} B S_{i k t-1}+u_{i k t}
$$

The notation and the rest of the notes are similar to Table 4 . Two differences exist. First, we do not include the inflation rate in the equation and, second, two additional terms appear - a bank-specific characteristic (capitalization) and its interaction with the monetary policy indicator. For the Eurogroup, instruments include the second lag in all cases. For Denmark, instruments include the first lag in Models II and IV, the second lag in Model III, and the third lag in Model I for the monetary policy indicator. We use the second lag as an instrument for the real GDP growth rate in all Models. In the UK case, instruments for the monetary policy indicator include the second lag in Model II and the third lag in the rest of the Models. We use the first lag as an instrument for the real GDP growth rate in Model II and the second lag in the rest of the models. Finally, we use the first lag as an instrument for capitalization in all cases and in all countries. We use the second lag as an instrument for the lagged loans in all cases as well. 
Table 6: The bank lending channel results for the Eurogroup, Denmark, and the United Kingdom, including size as bank-specific characteristic.

\begin{tabular}{|c|c|c|c|c|c|c|c|c|}
\hline \multirow[b]{3}{*}{ Eurogroup } & \multicolumn{8}{|c|}{ Dependent variable: Annual growth rate of lending } \\
\hline & \multicolumn{2}{|c|}{$\begin{array}{c}\text { Monetary policy } \\
\text { indicator: } \\
\text { ECB rate } \\
\text { (Model I) }\end{array}$} & \multicolumn{2}{|c|}{$\begin{array}{l}\text { Monetary policy } \\
\text { indicator: } \\
\text { Backward rule } \\
\text { (Model II) }\end{array}$} & \multicolumn{2}{|c|}{$\begin{array}{c}\text { Monetary policy } \\
\text { indicator: } \\
\text { Taylor rule } \\
\text { (Model III) }\end{array}$} & \multicolumn{2}{|c|}{$\begin{array}{l}\text { Monetary policy } \\
\text { indicator: } \\
\text { Forward rule } \\
\text { (Model IV) }\end{array}$} \\
\hline & Coef. & Prob & Coef. & Prob & Coef. & Prob & Coef. & Prob \\
\hline$\Delta i_{k t-1}$ & -0.6260 & 0.0392 & -0.8028 & 0.0604 & -0.6763 & 0.0809 & -0.6907 & 0.0016 \\
\hline$\Delta \ln G D P_{k t}$ & & & 0.4803 & 0.0016 & & & & \\
\hline$\Delta \ln G D P_{k t-1}$ & 0.9039 & 0.0134 & & & 1.1776 & 0.0009 & 0.7129 & 0.0176 \\
\hline Size $_{i k t-1}$ & 0.0571 & 0.0000 & 0.0746 & 0.0000 & 0.0579 & 0.0000 & 0.0480 & 0.0000 \\
\hline$\Delta i_{k t-1} * S_{i z e_{i k t-1}}$ & -1.9926 & 0.3438 & -17.3960 & 0.0000 & -1.4896 & 0.4120 & 7.3599 & 0.0370 \\
\hline Denmark & Coef. & $\underline{\text { Prob }}$ & Coef. & Prob & Coef. & Prob & Coef. & Prob \\
\hline$\Delta i_{k t}$ & & & -2.6435 & 0.0000 & & & -0.0616 & 0.6868 \\
\hline$\Delta i_{k t-1}$ & & & & & -14.9740 & 0.0000 & & \\
\hline$\Delta i_{k t-2}$ & -0.9977 & 0.0000 & & & & & & \\
\hline$\Delta \ln G D P_{k t-1}$ & 3.3829 & 0.0000 & 4.2513 & 0.0000 & 7.9619 & 0.0000 & 3.3863 & 0.0000 \\
\hline Size $_{\text {ikt-1 }}$ & 0.0297 & 0.0000 & 0.0621 & 0.0000 & 0.0483 & 0.0000 & 0.0446 & 0.0000 \\
\hline$\Delta i_{k t} * S_{i z e_{i k t-1}}$ & & & 3.5655 & 0.0000 & & & 0.7395 & 0.0000 \\
\hline$\Delta i_{k t-1} * S_{i z e} e_{i k t-1}$ & & & & & 3.6328 & 0.0000 & & \\
\hline$\Delta i_{k t-2} * \operatorname{Size}_{i k t-1}$ & -1.8848 & 0.0000 & & & & & & \\
\hline U.K. & Coef. & Prob & Coef. & Prob & Coef. & Prob & Coef. & Prob \\
\hline$\Delta i_{k t-1}$ & -0.3618 & 0.4792 & -19.8440 & 0.0000 & -26.7560 & 0.0000 & & \\
\hline$\Delta i_{k t-2}$ & & & & & & & -30.7020 & 0.0000 \\
\hline$\Delta \ln G D P_{k t}$ & & & 1.5952 & 0.0000 & & & & \\
\hline$\Delta \ln G D P_{k t-1}$ & 1.1387 & 0.0004 & & & 1.4895 & 0.0002 & 0.6117 & 0.2809 \\
\hline Size $_{\text {ikt-1 }}$ & 0.0198 & 0.0004 & 0.2600 & 0.0000 & -0.0639 & 0.0000 & -0.0739 & 0.0000 \\
\hline$\Delta i_{k t-1} * S_{i z e_{i k t-1}}$ & 8.1192 & 0.0000 & -15.7370 & 0.0607 & 39.5253 & 0.0001 & & \\
\hline$\Delta i_{k t-2} * S i z e_{i k t-1}$ & & & & & & & 40.5341 & 0.0000 \\
\hline
\end{tabular}

Note: $\quad$ See Table 4 . The models are given by the following equation:

$$
\Delta \ln L_{i k t}=a_{k}+\varphi_{i k} \Delta \ln L_{i k t-1}+\sum_{j=0}^{n} \beta_{j} \Delta i_{k t-j}+\sum_{j=0}^{n} \delta_{j} \Delta \ln G D P_{k t-j}+\gamma_{i k} B S_{i k t-1}+\sum_{j=0}^{n} \lambda_{j} \Delta i_{k t-j} B S_{i k t-1}+u_{i k t}
$$

The notation and the rest of the notes are similar to Table 4. Two differences exist. First, we do not include the inflation rate in the equation and, second, two additional terms appear - a bank-specific characteristic (size) and its interaction with the monetary policy indicator. For the Eurogroup, instruments include the second lag for the monetary policy indicator, whereas for the real GDP growth rate we use the first lag in Model II and the second lag in the rest of the Models. For Denmark, instruments include the first lag in Models II and IV, the second lag in Model III, and the third lag in Model I for the monetary policy indicator. We use the second lag as an instrument for the real GDP growth rate in all Models. In the UK, instruments for the monetary policy indicator include the second lag in Models I, II, and III and the third lag in Model IV. We use the first lag as an instrument for the real GDP growth rate in Model II and the second lag in the rest of the models. Finally, we use the first lag as an instrument for size in all cases and in all countries. We use the second lag for the lagged loans as an instrument in all cases as well. 
Table 7: $\quad$ The bank lending channel results for the Eurogroup, Denmark, and the United Kingdom, including liquidity as bank-specific characteristic.

\begin{tabular}{|c|c|c|c|c|c|c|c|c|}
\hline \multirow[b]{3}{*}{ Eurogroup } & \multicolumn{8}{|c|}{ Dependent variable: Annual growth rate of lending } \\
\hline & \multicolumn{2}{|c|}{$\begin{array}{c}\text { Monetary policy } \\
\text { indicator: } \\
\text { ECB rate } \\
\text { (Model I) } \\
\end{array}$} & \multicolumn{2}{|c|}{$\begin{array}{c}\text { Monetary policy } \\
\text { indicator: } \\
\text { Backward rule } \\
\text { (Model II) } \\
\end{array}$} & \multicolumn{2}{|c|}{$\begin{array}{c}\text { Monetary policy } \\
\text { indicator: } \\
\text { Taylor rule } \\
\text { (Model III) } \\
\end{array}$} & \multicolumn{2}{|c|}{$\begin{array}{l}\text { Monetary policy } \\
\text { indicator: } \\
\text { Forward rule } \\
\text { (Model IV) } \\
\end{array}$} \\
\hline & Coef. & Prob & Coef. & Prob & Coef. & Prob & Coef. & Prob \\
\hline$\Delta i_{k t-1}$ & -0.5648 & 0.1483 & & & -1.2088 & 0.0198 & & \\
\hline$\Delta i_{k t-2}$ & & & -1.5174 & 0.0500 & & & -1.6044 & 0.0289 \\
\hline$\Delta \ln G D P_{k t-1}$ & 1.0636 & 0.0049 & 0.7404 & 0.0001 & 2.6858 & 0.0000 & 0.9127 & 0.0010 \\
\hline $\operatorname{Liq}_{i k t-1}$ & 0.0164 & 0.0000 & 0.0187 & 0.0000 & 0.0098 & 0.0026 & 0.0444 & 0.0001 \\
\hline$\Delta i_{k t-1} * L i q_{i k t-1}$ & 0.6920 & 0.6554 & & & 4.1788 & 0.0005 & & \\
\hline$\Delta i_{k t-2} * L i q_{i k t-1}$ & & & 12.2259 & 0.0111 & & & 22.6709 & 0.0000 \\
\hline Denmark & Coef. & Prob & Coef. & Prob & Coef. & Prob & Coef. & Prob \\
\hline$\Delta i_{k t}$ & & & -1.4331 & 0.0000 & & & & \\
\hline$\Delta i_{k t-1}$ & & & & & -14.9980 & 0.0000 & & \\
\hline$\Delta i_{k t-2}$ & -1.0845 & 0.0035 & & & & & -2.5178 & 0.0000 \\
\hline$\Delta \ln G D P_{k t-1}$ & 3.4278 & 0.0000 & 4.2187 & 0.0000 & 7.9890 & 0.0000 & 3.2893 & 0.0000 \\
\hline $\operatorname{Liq}_{i k t-1}$ & 0.0253 & 0.0011 & 0.0147 & 0.0000 & 0.0266 & 0.0000 & 0.0210 & 0.0002 \\
\hline$\Delta i_{k t}{ }^{*} L_{i q} q_{i k t-1}$ & & & 4.2437 & 0.0000 & & & & \\
\hline$\Delta i_{k t-1} * L i q_{i k t-1}$ & & & & & 0.5100 & 0.3022 & & \\
\hline$\Delta i_{k t-2} * L i q_{i k t-1}$ & 17.2301 & 0.0000 & & & & & 22.2071 & 0.0000 \\
\hline U.K. & Coef. & Prob & Coef. & Prob & Coef. & Prob & Coef. & Prob \\
\hline$\Delta i_{k t-1}$ & -2.5036 & 0.0569 & -8.6421 & 0.0000 & & & & \\
\hline$\Delta i_{k t-2}$ & & & & & -18.6640 & 0.0182 & -13.8750 & 0.0000 \\
\hline$\Delta \ln G D P_{k t}$ & & & 1.2706 & 0.0000 & & & & \\
\hline$\Delta \ln G D P_{k t-1}$ & 0.8082 & 0.0097 & & & 1.2609 & 0.0158 & 1.0183 & 0.0012 \\
\hline $\operatorname{Liq}_{i k t-1}$ & 0.0231 & 0.0005 & 0.0427 & 0.0000 & 0.0640 & 0.0000 & 0.0616 & 0.0000 \\
\hline$\Delta i_{k t-1} * L i q_{i k t-1}$ & 0.7010 & 0.8710 & -25.5600 & 0.0000 & & & & \\
\hline$\Delta i_{k t-2} * L i q_{i k t-1}$ & & & & & -22.9770 & 0.0100 & 26.0581 & 0.0000 \\
\hline
\end{tabular}

Note: See Table 4. The models are given by the following equation:

$$
\Delta \ln L_{i k t}=a_{k}+\varphi_{i k} \Delta \ln L_{i k t-1}+\sum_{j=0}^{n} \beta_{j} \Delta i_{k t-j}+\sum_{j=0}^{n} \delta_{j} \Delta \ln G D P_{k t-j}+\gamma_{i k} B S_{i k t-1}+\sum_{j=0}^{n} \lambda_{j} \Delta i_{k t-j} B S_{i k t-1}+u_{i k t}
$$

The notation and the rest of the notes are similar to Table 4 . Two differences exist. First, we do not include the inflation rate in the equation and, second, two additional terms appear - a bank-specific characteristic (liquidity) and its interaction with the monetary policy indicator. For the Eurogroup, instruments include the second lag in Models I and III and the third lag in Models II and IV for the monetary policy indicator, whereas for the real GDP growth rate, we use the second lag in all Models. For Denmark, instruments include the first lag in Model II, the second lag in Model III, and the third lag in Models I and IV for the monetary policy indicator. We use the second lag as an instrument for the real GDP growth rate in all Models. In the UK, instruments for the monetary policy indicator include the second lag in Models I and II and the third lag in Models III and IV. We use the second lag as an instrument for the real GDP growth rate in Model II and the second lag in the rest of the models. Finally, we use the first lag as an instrument for liquidity in all cases and in all countries. We use the second lag for the lagged loans as an instrument in all cases as well. 
Table 8: $\quad$ The bank lending channel results for the Eurogroup, Denmark, and the United Kingdom, including the growth rate of real consumption.

\begin{tabular}{|c|c|c|c|c|c|c|c|c|}
\hline \multirow[b]{3}{*}{ Eurogroup } & \multicolumn{8}{|c|}{ Dependent variable: Annual growth rate of lending } \\
\hline & \multicolumn{2}{|c|}{$\begin{array}{l}\text { Monetary policy } \\
\text { indicator: } \\
\text { ECB rate } \\
\text { (Model I) }\end{array}$} & \multicolumn{2}{|c|}{$\begin{array}{l}\text { Monetary policy } \\
\text { indicator: } \\
\text { Backward rule } \\
\text { (Model II) }\end{array}$} & \multicolumn{2}{|c|}{$\begin{array}{l}\text { Monetary policy } \\
\text { indicator: } \\
\text { Taylor rule } \\
\text { (Model III) }\end{array}$} & \multicolumn{2}{|c|}{$\begin{array}{l}\text { Monetary policy } \\
\text { indicator: } \\
\text { Forward rule } \\
\text { (Model IV) }\end{array}$} \\
\hline & Coef. & $\underline{\text { Prob }}$ & Coef. & $\underline{\text { Prob }}$ & Coef. & $\underline{\text { Prob }}$ & Coef. & Prob \\
\hline$\Delta i_{k t-1}$ & -0.6791 & 0.0115 & -1.1602 & 0.0017 & & & -0.3997 & 0.2545 \\
\hline$\Delta i_{k t-2}$ & & & & & -1.6219 & 0.0014 & & \\
\hline $\begin{array}{l}\Delta l n C o n_{k t} \\
\Delta \ln \operatorname{Con}_{k t-1}\end{array}$ & 1.0055 & 0.0000 & 0.8746 & 0.0183 & 0.7655 & 0.0105 & 0.7907 & 0.0000 \\
\hline Denmark & Coef. & $\underline{\text { Prob }}$ & Coef. & Prob & Coef. & $\underline{\text { Prob }}$ & Coef. & Prob \\
\hline$\Delta i_{k t-1}$ & & & -1.3678 & 0.0000 & -0.4448 & 0.0180 & & \\
\hline$\Delta i_{k t-2}$ & -0.0859 & 0.4594 & & & & & -2.3790 & 0.0000 \\
\hline$\Delta \operatorname{lnCon}_{k t}$ & 3.0108 & 0.0000 & & & 3.3027 & 0.0000 & & \\
\hline$\Delta \ln \operatorname{Con}_{k t-1}$ & & & 2.4957 & 0.0000 & & & 4.1339 & 0.0000 \\
\hline U.K. & Coef. & Prob & Coef. & Prob & Coef. & Prob & Coef. & Prob \\
\hline$\Delta i_{k t-1}$ & & & -1.3519 & 0.0000 & & & & \\
\hline$\Delta i_{k t-2}$ & -1.1132 & 0.0000 & & & -2.7047 & 0.0000 & -2.7452 & 0.0000 \\
\hline$\Delta \ln \operatorname{Con}_{k t}$ & 0.7212 & 0.0000 & 1.4269 & 0.0000 & & & & \\
\hline$\Delta \ln \operatorname{Con}_{k t-1}$ & & & & & 0.9974 & 0.0000 & 1.1538 & 0.0000 \\
\hline
\end{tabular}

Note: $\quad$ See Table 4 . The models are given by the following equation:

$$
\Delta \ln L_{i k t}=a_{k}+\varphi_{i k} \Delta \ln L_{i k t-1}+\sum_{j=0}^{n} \beta_{j} \Delta i_{k t-j}+\sum_{j=0}^{n} \delta_{j} \Delta \ln C_{0 o} n_{k t-j}+u_{i k t}
$$

The notation and the rest of the notes are similar to Table 4. Two differences exist. First, we do not include the inflation rate and real GDP growth rate, replacing them with the growth rate of real consumption spending, $\Delta \operatorname{lnCon}_{k t-j .}$. For the Eurogroup, instruments include the second lag in Models I, II, and IV and the third lag in Model III for the monetary policy indicator whereas for the growth rate of real consumption spending, we use the first lag in Models I, II, and IV and the second lag in Model III. For Denmark, instruments include the second lag in Models II and III and the third lag in Model I and IV for the monetary policy indicator. We use the first lag as an instrument for the growth rate of real consumption spending in Models I and III and the second lag in Models II and IV. In the UK, instruments for the monetary policy indicator include the second lag in Model II and the third lag in the rest of the Models. We use the first lag as an instrument for the growth rate of real consumption spending in Models I and II and the second lag in the rest of the models. We use the second lag for the lagged loans as an instrument in all cases. 
Table 9: $\quad$ The bank lending channel results for the Eurogroup, Denmark, and the United Kingdom, including the ratio loans to total deposits.

\begin{tabular}{|c|c|c|c|c|c|c|c|c|}
\hline \multirow[b]{3}{*}{ Eurogroup } & \multicolumn{8}{|c|}{ Dependent variable: Annual growth rate of lending } \\
\hline & \multicolumn{2}{|c|}{$\begin{array}{l}\text { Monetary policy } \\
\text { indicator: } \\
\text { ECB rate } \\
\text { (Model I) } \\
\end{array}$} & \multicolumn{2}{|c|}{$\begin{array}{l}\text { Monetary policy } \\
\text { indicator: } \\
\text { Backward rule } \\
\text { (Model II) } \\
\end{array}$} & \multicolumn{2}{|c|}{$\begin{array}{c}\text { Monetary policy } \\
\text { indicator: } \\
\text { Taylor rule } \\
\text { (Model III) } \\
\end{array}$} & \multicolumn{2}{|c|}{$\begin{array}{c}\text { Monetary policy } \\
\text { indicator: } \\
\text { Forward rule } \\
\text { (Model IV) } \\
\end{array}$} \\
\hline & Coef. & Prob & Coef. & Prob & Coef. & Prob & Coef. & Prob \\
\hline$\Delta i_{k t-1}$ & -0.7855 & 0.0151 & -1.0080 & 0.0418 & & & -1.0478 & 0.0420 \\
\hline$\Delta i_{k t-2}$ & & & & & -1.0127 & 0.0102 & & \\
\hline$\Delta \ln G D P_{k t-1}$ & 1.1762 & 0.0013 & 1.9991 & 0.0000 & 0.0366 & 0.8324 & 0.8904 & 0.0044 \\
\hline $\ln \left(L / \operatorname{Dep}_{i k}\right)$ & 0.0001 & 0.0277 & & & 0.0001 & 0.0185 & 0.0001 & 0.0313 \\
\hline $\ln \left(L / D e p_{i k t-1}\right)$ & & & -0.0002 & 0.1568 & & & & \\
\hline Denmark & Coef. & Prob & Coef. & Prob & Coef. & Prob & Coef. & Prob \\
\hline$\Delta i_{k t}$ & & & & & & & -1.0689 & 0.0000 \\
\hline$\Delta i_{k t-1}$ & & & -1.7002 & 0.0000 & -15.0473 & 0.0000 & & \\
\hline$\Delta i_{k t-2}$ & -2.1832 & 0.0000 & & & & & & \\
\hline$\Delta \ln G D P_{k t}$ & & & 0.2137 & 0.0000 & & & & \\
\hline$\Delta \ln G D P_{k t-1}$ & 3.0431 & 0.0000 & & & 7.5497 & 0.0000 & 4.0320 & 0.0000 \\
\hline $\ln \left(L / D e p_{i k}\right)$ & 0.1979 & 0.0000 & & & 0.2213 & 0.0000 & 0.0524 & 0.0000 \\
\hline $\ln \left(L / \operatorname{Dep}_{i k t-1}\right)$ & & & -0.1306 & 0.0000 & & & & \\
\hline U.K. & Coef. & Prob & Coef. & Prob & Coef. & Prob & Coef. & Prob \\
\hline$\Delta i_{k t-1}$ & -2.0224 & 0.0032 & 20.6942 & 0.0000 & -35.2343 & 0.0000 & & \\
\hline$\Delta i_{k t-2}$ & & & & & & & -24.8312 & 0.0000 \\
\hline$\Delta \ln G D P_{k t}$ & & & 1.7804 & 0.0000 & & & & \\
\hline$\Delta \ln G D P_{k t-1}$ & 1.2954 & 0.0000 & & & 2.1354 & 0.0000 & 1.1446 & 0.0000 \\
\hline $\ln \left(L / D e p_{i k}\right)$ & & & 0.0234 & 0.0002 & & & 0.0024 & 0.7431 \\
\hline $\ln \left(L / D e p_{i k t-1}\right)$ & -0.0323 & 0.1303 & & & -0.0460 & 0.1066 & & \\
\hline
\end{tabular}

Note: $\quad$ See Table 4 . The models are given by the following equation:

$$
\Delta \ln L_{i k t}=a_{k}+\varphi_{i k} \Delta \ln L_{i k t-1}+\sum_{j=0}^{n} \beta_{j} \Delta i_{k t-j}+\sum_{j=0}^{n} \delta_{j} \Delta \ln G D P_{k t-j}+\sum_{j=0}^{n} \gamma_{j} \ln \left(L / D e p_{i k t-j}\right)+u_{i k t}
$$

The notation and the rest of the notes are similar to Table 4. Two differences exist. First, we do not include the inflation rate in the equation and, second, we include one additional variable - the ratio loans/total deposits of bank $L /$ Dep $_{i k t-j}$. For the Eurogroup, instruments include the first lag in Model II, the second lag in Models I and IV, and the third lag in Model III for the monetary policy indicator, whereas for the real GDP growth rate, we use the second lag in all Models. We use the first lag as an instrument for the ratio in Models I, III, and IV and the second lag in Model II. For Denmark, instruments include the first lag in Model IV, the second lag in Models II and III, and the third lag in Model I for the monetary policy indicator. We use the first lag as an instrument for the real GDP growth rate in Model II and the second lag in the rest of the Models. We use the first lag as an instrument for the ratio in Models III and IV and the second lag in Models I and II. In the UK, instruments for the monetary policy indicator include the second lag in Models I, II, and III and the third lag in Model IV. We use the first lag as an instrument for the real GDP growth rate in Model II and the second lag in the rest of the models. Finally, we use the first lag as an instrument for the ratio in Models II and IV and the second lag in Models I and III. We use the second lag for the lagged loans as an instrument in all cases. 
Table 10: The bank lending channel results for the Eurogroup, Denmark, and the United Kingdom, including the growth rate of total deposits.

\begin{tabular}{|c|c|c|c|c|c|c|c|c|}
\hline \multirow[b]{3}{*}{ Eurogroup } & \multicolumn{8}{|c|}{ Dependent variable: Annual growth rate of lending } \\
\hline & \multicolumn{2}{|c|}{$\begin{array}{c}\text { Monetary policy } \\
\text { indicator: } \\
\text { ECB rate } \\
\text { (Model I) } \\
\end{array}$} & \multicolumn{2}{|c|}{$\begin{array}{l}\text { Monetary policy } \\
\text { indicator: } \\
\text { Backward rule } \\
\text { (Model II) } \\
\end{array}$} & \multicolumn{2}{|c|}{$\begin{array}{l}\text { Monetary policy } \\
\text { indicator: } \\
\text { Taylor rule } \\
\text { (Model III) } \\
\end{array}$} & \multicolumn{2}{|c|}{$\begin{array}{l}\text { Monetary policy } \\
\text { indicator: } \\
\text { Forward rule } \\
\text { (Model IV) } \\
\end{array}$} \\
\hline & Coef. & Prob & Coef. & Prob & Coef. & Prob & Coef. & Prob \\
\hline$\Delta i_{k t}$ & & & & & -0.3802 & 0.0093 & & \\
\hline$\Delta i_{k t-1}$ & -0.5338 & 0.0726 & -0.8672 & 0.0188 & & & -1.4239 & 0.0000 \\
\hline$\Delta \ln G D P_{k t}$ & & & 0.3571 & 0.0062 & 0.5917 & 0.0000 & & \\
\hline$\Delta \ln G D P_{k t-1}$ & 0.7414 & 0.0417 & & & & & 0.8807 & 0.0000 \\
\hline$\Delta \ln \left(D_{e} p_{i k}\right)$ & 0.1710 & 0.0000 & 0.1750 & 0.0000 & 0.1652 & 0.0000 & 0.2388 & 0.0000 \\
\hline Denmark & Coef. & $\underline{\text { Prob }}$ & Coef. & $\underline{\text { Prob }}$ & Coef. & Prob & Coef. & $\underline{\text { Prob }}$ \\
\hline$\Delta i_{k t}$ & & & & & & & -0.7169 & 0.0001 \\
\hline$\Delta i_{k t-1}$ & & & -1.3782 & 0.0000 & -1.3018 & 0.0000 & & \\
\hline$\Delta i_{k t-2}$ & -1.1829 & 0.0000 & & & & & & \\
\hline$\Delta \ln G D P_{k t}$ & & & 0.2493 & 0.0000 & & & & \\
\hline$\Delta \ln G D P_{k t-1}$ & 0.2904 & 0.0000 & & & 0.7178 & 0.0000 & 0.3775 & 0.0000 \\
\hline$\Delta \ln \left(D_{e} p_{i k}\right)$ & 0.4079 & 0.0000 & 0.3505 & 0.0000 & 0.3246 & 0.0000 & & \\
\hline$\Delta \ln \left(\operatorname{Dep}_{i k t-1}\right)$ & & & & & & & -0.2556 & 0.0000 \\
\hline U.K. & Coef. & $\underline{\text { Prob }}$ & Coef. & $\underline{\text { Prob }}$ & Coef. & $\underline{\text { Prob }}$ & Coef. & $\underline{\text { Prob }}$ \\
\hline$\Delta i_{k t-1}$ & -1.4980 & 0.0013 & -13.2820 & 0.0000 & & & & \\
\hline$\Delta i_{k t-2}$ & & & & & -2.9676 & 0.6329 & -12.7300 & 0.0042 \\
\hline$\Delta \ln G D P_{k t}$ & 0.2894 & 0.0000 & 0.8931 & 0.0000 & 0.1540 & 0.0937 & & \\
\hline$\Delta \ln G D P_{k t-1}$ & & & & & & & 0.5680 & 0.0285 \\
\hline$\Delta \ln \left(D_{e p}{ }_{i k}\right)$ & 0.3452 & 0.0000 & 0.4108 & 0.0000 & 0.4785 & 0.0000 & 0.4415 & 0.0000 \\
\hline
\end{tabular}

Note: See Table 4 . The models are given by the following equation:

$$
\Delta \ln L_{i k t}=a_{k}+\varphi_{i k} \Delta \ln L_{i k t-1}+\sum_{j=0}^{n} \beta_{j} \Delta i_{k t-j}+\sum_{j=0}^{n} \delta_{j} \Delta \ln G D P_{k t-j}+\sum_{j=0}^{n} \gamma_{j} \Delta \ln \left(D e p_{i k t-j}\right)+u_{i k t}
$$

The notation and the rest of the notes are similar to Table 4 . Two differences exist. First, we do not include the inflation rate in the equation and, second, we include one additional variable - the growth rate of total deposits $\Delta \ln \left(D e p_{i k t-j}\right)$. For the Eurogroup, instruments include the first lag in Model III and the second lag in the rest of the Models, for the monetary policy indicator, whereas for the real GDP growth rate, we use the first lag in Models II and III and the second lag in Models I and IV. We use the first lag as an instrument for total deposits in all Models. For Denmark, instruments for the monetary policy indicator and the GDP growth match those in Table 9. For total deposits, we use the first lag as an instrument in Models I, II, and III and the second lag in Model IV. In the UK, instruments for the monetary policy indicator include the second lag in Models I and II and the third lag in Models III and IV. We use the first lag as an instrument for the real GDP growth rate in Models I, II, and III and the second lag in Model IV. Finally, we use the first lag as an instrument for total deposits in all Models. We use the second lag for the lagged loans as an instrument in all cases. 